\title{
Sustainability and Retail: Analysis of Global Research
}

\author{
José Luis Ruiz-Real *, Juan Uribe-Toril@, Juan Carlos Gázquez-Abad $(\mathbb{D}$ \\ and Jaime de Pablo Valenciano \\ Faculty of Economics and Business, University of Almeria, Ctra. De Sacramento, s/n, 04120 Almería, Spain; \\ juribe@ual.es (J.U.-T.); jcgazque@ual.es (J.C.G.-A.); jdepablo@ual.es (J.d.P.V.) \\ * Correspondence: jlruizreal@ual.es; Tel.: +34-950-015742
}

Received: 27 November 2018; Accepted: 18 December 2018; Published: 20 December 2018

\begin{abstract}
In recent years, the topic of sustainability has gained prominence in many retail sectors. Sustainability is a key element for retailers, who have seen that sustainable development could become an important source of competitive advantage. The purpose of this work is to highlight state of the art sustainability in retailing, for which a bibliometric analysis has been carried out using Web of Science online and Scopus database. Our findings show the most influential countries, journals, authors, and areas of knowledge interested in the topic. By using a fractional counting method to analyze co-occurrence of the author's keywords, this paper identifies the most frequent terms and seven clusters. This article represents a contribution by identifying the main trends in sustainability and retail research and proposes future research initiatives, such as: analyze under which conditions the sustainability initiatives give better results to retailers; selection of suppliers and supply chain management; evaluate different types of sustainable products; store sustainable management; sustainability actions and retailers image; how to communicate the sustainability actions of retailers; how sustainability actions influence different types of brands; and international and cross-cultural analysis.
\end{abstract}

Keywords: retailing; sustainability; bibliometric; WOS; Scopus

\section{Introduction}

In recent years, the issue of sustainability has grown at a great pace, taking on a special relevance in our society and now becoming one of the most important management elements for both governments and companies. Multiple definitions of sustainability can be found in the literature, often using different terminology, but it remains difficult to express it in concrete operational terms [1]. As such, there is no one universal understanding of the term, which could be partially explained by its transversal nature and by the diversity of areas of knowledge and specific issues with which it is related. It seems that one of the currents with more strength is the one that links sustainability with the Triple Bottom Line (TBL) model, developed by Elkington [2] for adapting sustainability to the business environment and incorporating three pillars, the economic, environmental and social dimensions of sustainability, and the interdependencies between them.

Thus, the topic of sustainability has gained importance in many business areas. Specifically, it has come to become a key element for retailers, who must pursue the benefits of economy activity, but within the principles of sustainable development [3] to introduce sustainability as a core value and practice. Retailers act as intermediaries between producers and consumers [4], so the introduction of sustainability as a core value in retailers is one of society's most promising means of safeguarding natural resources [5]. There are many different ways in which retailers can influence society and help the development of a more sustainable environment. Mainly it could differentiate between those activities more focused on social issues, and those that focus on environmental sustainability. 
A relevant aspect of the relationship between retailers and sustainability is the importance of the different stakeholders in sustainable retail sales and the impact they have on their activity [6]. In this same sense, Maignan et al. [7] argue that retailers must find a balance between market demand and stakeholder expectations to be successful in sustainable retailing. Retail practices are positioned in between upstream and downstream practices and they form a kind of hybrid in between life-world and system rationalities, referred to as "consumption junctions" [8].

In order to favor more sustainable behavior in their products and production processes (e.g., logistics, packaging, or assortment), retailers can pressure their suppliers to achieve more sustainable business models, as well as promote and encourage changes in consumer behavior that improve social and environmental issues [9]. This is a fundamental aspect that also provides real value to retailers, since many current consumers are prone to identifying themselves with the values of the companies and the brands they buy, looking for aspects that not only regard price or product quality, but also of having shared values and social ties [10]. People are demanding sustainable products, and trends such as ethical consumerism and corporate social responsibility are taking an important role, and for retailers the ability to create economic value and ethical values coincide [11]. Because of the prominent position that retailers occupy in the market, they have become a key element to promote and consolidate changes in market processes [12]. Therefore, there are numerous policymakers assessing ways to promote sustainable consumption and production of retailers [13], but this is not only in the sphere of public organizations. In Europe, for example, apart from public entities (e.g., European Commission, or national governments) there are several movements from civil society organizations trying to increase retailers' commitment to sustainable consumption and production. Environmental awareness and the importance of sustainable practices have increased considerably in recent years, so consumers are now much more sensitive to companies' sustainable and environmental care practices, reacting more sensitively towards some issues, such as the eco-friendliness of product offering [14].

A relevant consequence of Corporate Social Responsibility (CSR) is a relationship development model in which all the involved subjects can benefit, including smaller partners inside the supply chain [15]. Thus, retailers look for incorporating sustainability considerations and enhance and communicate their corporate social responsibility [16]. Retailers can gain competitive advantages by incorporating sustainability issues [17] and corporate responsibility [18], as well as gain greater respectability and credibility [19]. Among the many benefits and motivations for retailers of adopting sustainable commercial practices may include some functional ones (e.g., energy and water cost savings, capital cost savings), and others related to the image of the retailer, or greater commitment and awareness by workers (e.g., improved reputation, enhanced value, brand differentiation, improved marketability, attract new customer segments, or staff commitment to environmentally sustainable development) [20]. In their research, [21] provide retail management with a detailed account of which specific corporate behaviors consumers perceive as socially irresponsible. Consumers are willing to pay more for ethical products [22], and products with fair trade or organic labels have higher consumer interest [23].

Based on this, a growing number of retailers are integrating sustainability into their strategies [24], with a wide range of sustainability efforts [25]. Realizing sustainable development implies that companies need to measure the sustainability of their behavior, for which they are required to use sustainability indicators $[26,27]$ and identified key indicators, among which we can mention: water consumption, energy consumption, product and packaging recovery, customer complaints, occupational health and safety, NGO-retailer partnerships, consumer health and safety, training and career, personnel turnover and layoffs, innovation capabilities and R\&D expenditures, number of shareholders, and more. That is, they include economic, environmental, and social indicators. Standardization increases accountability and decreases costs of sustainable retailing [28]. Retailers may implement sustainability criteria internally, but frequently third parties are involved to guide them and to facilitate sustainability [29]. In this case, the model is usually based on standard certifications, covering multiple areas of sustainable retailing (e.g., agriculture, trading, etc.). 
Despite the importance of sustainability in retailing and the growing emergence of publications, the topic of sustainability is still little explored in retail research [16]. Although some authors have conducted studies on specific aspects of sustainable consumption and production [30,31], and others provide a conceptual description [6], there is not a complete picture of this issue in literature.

For all these reasons, the purpose of this research is to understand, from a bibliometric perspective on scientific literature, the state of art of sustainability in retail, the evolution of publications, authors, and the main areas of knowledge in which these investigations are framed. Bibliometric analysis allows evaluating developments in knowledge on a specific subject and assesses the scientific influence of research and sources [32]. Thus, this article represents a contribution to identify the main trends in retailing research and sustainability, and from there, propose future research initiatives. We carry out a bibliometric analysis, as detailed in the next section, in which the databases, the methodology of calculation, and tracking strategy used to obtain references are described. Subsequently, the main results obtained are presented and analyzed, concerning matters such as countries and languages of publication, annual evolution of the number of publications, the most influential journals and authors, as well as the main areas of knowledge in which the publications are framed. Finally, in the fourth section, final conclusions, implications, limitations of this research, and future potential research lines are presented.

\section{Methodology}

The rapid growth of scientific production in recent years and its collection in bibliographic databases allows the use of bibliometric analysis to measure scientific activity on specific topics. Thus, in order to analyze the evolution of retailing and sustainability in scientific publications, a bibliometric analysis was carried on. Therefore, this research is based on a systematic bibliographical analysis of the literature related to the mentioned topics, following a sequence of steps [33]: (1) define the search criteria, keywords and time periods; (2) selection of scientific datasets; (3) adjustment and refinement of research criteria; (4) full export of results; and (5) analysis of the information and discussion of the results (Figure 1).

Retailing and sustainability were the objective topics of this research. However, there are some terms that may be used interchangeably, for example "sustainability" and "sustainable development" [34]. Therefore, since we were interested not only in the central terms, but also in other words with common root and equivalent meaning (e.g., "retail" or "retailer", and, likewise, terms derived from sustainability, such as "sustainable"), taking advantage of some of the functions of the tools used in this analysis, we selected the terms retail* and sustainab to gain further insights into the research. Thus, we searched for articles containing these terms in the title, abstract, or keywords.

The next step was identifying publications from robust and reliable databases. One study [35] described a citation index for science. In order to avoid some of the limitations of using a single database, we develop the research based on two different platforms of scientific information, the publication of indexes in the Web of Science Thomson Reuters (WOS) online database core collection, and Scopus database. WOS and Scopus are the most widespread databases for different scientific fields and both are frequently used for searching literature [36]. WOS is a multidisciplinary database which mainly records scientific articles, reviews, and books (also other documents such as meetings, editorials, or letters). WOS is the most commonly used database, generating useful information for researchers evaluating scientific activity. It is also considered a good option due to its multidisciplinary character, the ability to filter searches using several bibliographic parameters, and because it provides easy access to the full texts of the searched papers. Scopus was developed in 2004 by the company Elsevier Science and it is a comprehensive scientific, medical, technical, and social science database containing all relevant literature. Some studies compare both databases [37], concluding that both of them have improved because of the competition [38].

A search in both databases, for identifying publications in journals indexed in them, was carried out. The preliminary results of this search, without applying any filters, were a total of 1727 references 
in WOS, and 2885 in Scopus. The results were adjusted and refined, according to the search criteria defined for this research. Thus, databases were subsequently filtered, redefining the date until 2017 (excluding publications of 2018, since the year is not finished at the moment this research was developed), and obtaining 1461 documents in WOS, and 2535 in Scopus. Finally, databases were again filtered to only include articles, which also facilitate and improve the analysis, since besides guaranteeing the quality of the publications, the journals include multidimensional elements, such as citation, year, or language [39]. After debugging the databases, the query on these terms in the titles, abstracts, and keywords resulted in 1076 documents in WOS, and 1572 in Scopus.

Once we obtained the final data, we exported the results with all available information in ".txt" format, which we used later for the bibliometric analysis. For the selected articles, the following issues were considered: number of annual publications, language, countries, journals, authors, and areas of knowledge. Bibliometric analyses are mainly based on two criteria: the scientific publication, as an indicator of research output [40], and citations received by them as a proxy of their scientific impact [41]. Thus, different bibliometric indicators were also used in this research to characterize the scientific output: the impact of papers, indicated by the number of references received from other subsequent publications (number of citations); frequency: by Hirsch index (h-index and averages), proposed by reference [42], and defined as the number of papers with citation number $\geq h$; and the impact factor of journals in the Journal Citation Report@ (JCR-Quartiles).

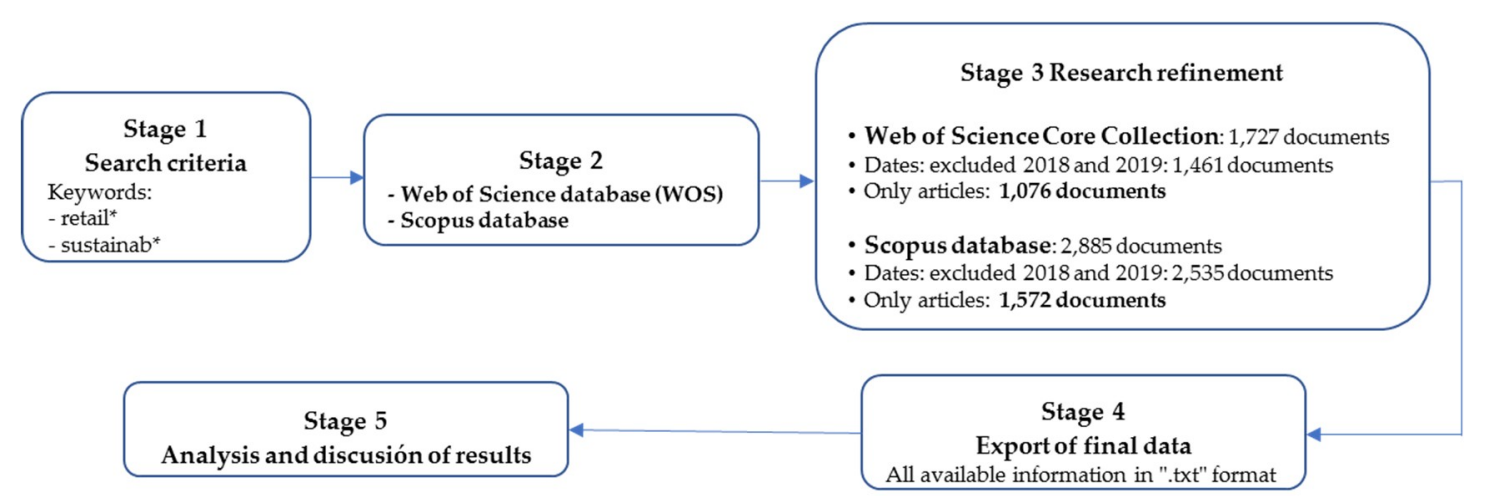

Figure 1. Five stages of WOS and Scopus bibliometric analysis.

Scopus covers larger journal collection than WOS. Checking the title list and DOI with journals indexed in both databases we identified the total number of distinct papers. The comparison of WOS and Scopus databases is shown in Figure 2.

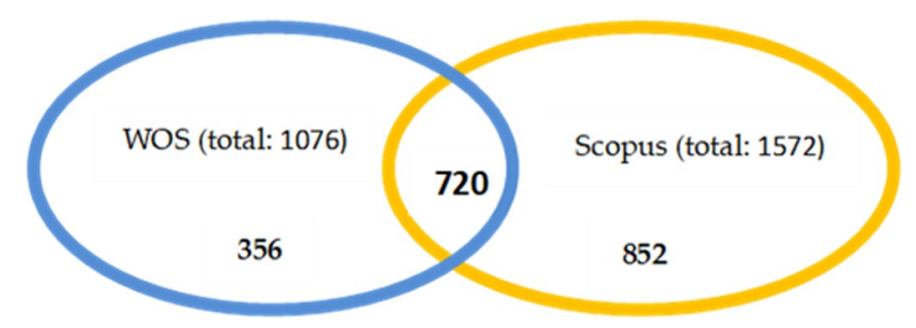

Figure 2. Comparison of papers in Web of Science and Scopus.

\section{Results and Discussion}

Sustainability in retail is an emergent topic, related to multiple issues (e.g., logistic, transport, cleaner production, cutting waste out of manufacturing process, eco-efficiency). Apart from ethical reasons, sustainable management offers other many advantages to retailers, and of course, also to consumers. Around 68 million consumers from the USA base purchasing decisions on their personal, social, and environmental values, and say they will spend up to $20 \%$ more on environmentally sound products [43], and consumers say sustainability marketing influences their purchases. However, 
according to Retail Industry Leaders Association [44], 93\% of consumers expect more of the brands they use to support social and environmental issues. Thus, retailers are increasing their commitment to sustainability. In this research, we focus on the scientific publications that connect both fields, sustainability and retailers, in order to know the current state, the evolution, and trend of literature, and the main implications for the future.

The most relevant results obtained are presented and analyzed in sub-sections which include the most influential countries and languages of publication, annual evolution of the number of publications, the most influential journals and authors, citations, as well as the main areas of knowledge in which the articles are framed.

\subsection{Most Influential Countries and Languages}

The United States of America (U.S.) and the United Kingdom (U.K.) lead the ranking of the most influential countries in WOS and Scopus (Table 1), both in volume of publications and citations. $42.6 \%$ (WOS) and $37.7 \%$ (Scopus) of articles related to sustainability in retail are concentrated in just these two countries. If we also consider Australian publications, the cumulative figures go up to $48.4 \%$ (WOS) and $42.2 \%$ (Scopus), which is evidence of the importance of this subject in the Anglo-Saxon world.

Table 1. Ranking of countries attending number of articles and citations (WOS and Scopus).

\begin{tabular}{|c|c|c|c|c|c|c|c|c|c|}
\hline \multirow[b]{2}{*}{ Country } & \multicolumn{4}{|c|}{ WOS } & \multicolumn{4}{|c|}{ SCOPUS } & \multirow[b]{2}{*}{ h-Index } \\
\hline & R W/S & A & $\mathrm{C}$ & C/A & h-Index & A & $\mathrm{C}$ & C/A & \\
\hline United States & $1 / 1$ & 257 & 5142 & 20.01 & 35 & 323 & 8182 & 25.33 & 37 \\
\hline United Kingdom & $2 / 2$ & 201 & 3645 & 18.13 & 35 & 263 & 4783 & 18.19 & 38 \\
\hline Netherlands & $3 / 3$ & 76 & 1355 & 17.83 & 20 & 80 & 1716 & 21.45 & 22 \\
\hline China & $4 / 6$ & 74 & 960 & 12.97 & 18 & 69 & 824 & 11.94 & 15 \\
\hline Australia & $5 / 4$ & 63 & 726 & 11.52 & 15 & 77 & 982 & 12.75 & 18 \\
\hline Sweden & $6 / 10$ & 60 & 649 & 10.82 & 16 & 55 & 829 & 15.07 & 19 \\
\hline Germany & $7 / 5$ & 59 & 603 & 10.22 & 16 & 70 & 856 & 12.23 & 17 \\
\hline Italy & $8 / 8$ & 52 & 733 & 14.10 & 15 & 66 & 799 & 12.11 & 16 \\
\hline Canada & $9 / 9$ & 49 & 605 & 12.35 & 13 & 57 & 760 & 13.33 & 17 \\
\hline Spain & $10 / 12$ & 39 & 430 & 11.03 & 13 & 42 & 531 & 12.64 & 15 \\
\hline South Africa & $11 / 14$ & 35 & 149 & 4.26 & 7 & 40 & 288 & 7.20 & 10 \\
\hline France & $12 / 11$ & 33 & 503 & 15.24 & 10 & 45 & 1435 & 31.89 & 10 \\
\hline India & $13 / 7$ & 29 & 412 & 14.21 & 10 & 66 & 527 & 7.98 & 11 \\
\hline Denmark & $14 / 15$ & 25 & 345 & 13.80 & 12 & 26 & 430 & 16.54 & 13 \\
\hline Brazil & $15 / 13$ & 23 & 168 & 7.30 & 6 & 40 & 228 & 5.70 & 7 \\
\hline Belgium & $16 / 22$ & 22 & 195 & 8.86 & 7 & 18 & 168 & 9.33 & 6 \\
\hline Norway & $16 / 16$ & 22 & 280 & 12.73 & 10 & 23 & 334 & 14.52 & 12 \\
\hline Switzerland & $16 / 17$ & 22 & 325 & 14.77 & 10 & 22 & 495 & 22.50 & 12 \\
\hline Turkey & $19 / 23$ & 21 & 217 & 10.33 & 7 & 18 & 292 & 16.22 & 8 \\
\hline Finland & $20 / 21$ & 19 & 208 & 10.95 & 7 & 19 & 207 & 10.89 & 7 \\
\hline New Zealand & $21 / 19$ & 18 & 204 & 11.33 & 9 & 21 & 348 & 16.57 & 11 \\
\hline Taiwan & $21 / 18$ & 18 & 178 & 9.89 & 6 & 22 & 213 & 9.68 & 8 \\
\hline Japan & $23 / 20$ & 16 & 243 & 15.19 & 7 & 20 & 197 & 9.85 & 6 \\
\hline South Korea & $24 / 25$ & 15 & 67 & 4.47 & 4 & 15 & 85 & 5.67 & 5 \\
\hline Austria & 25 & 14 & 87 & 6.21 & 4 & & & & \\
\hline
\end{tabular}

R W/S: Ranking on WOS (W) and Scopus (S) databases. A: total number of articles. C: total number of citations in total articles. C/A: average citations per article. h-Index: Hirsch index.

Regarding other indices, such as total citations per article and the h-index, the ranking remains unchanged in the first two positions (U.S. and U.K.) in both databases, although the cumulative relative weight is higher in Scopus (50.5\%) than in WOS (47.7\%). The h-index is also higher in Scopus (38 in the United Kingdom, 37 in the United States) than in WOS (35 in both countries). Other countries, such as The Netherlands, China, Germany, Sweden, or Italy, make up a second interest group in the ranking of 
publications. A broad representation of European countries and some Asian countries can be found in the ranking, however, only Brazil represents South America.

As could be expected, and coinciding with the mother tongue of the most influential countries in terms of publications in the topic under analysis in this research, English stands out well above other languages, monopolizing 97.4\% (WOS) and 94.6\% (Scopus) of articles (Table 2). Since the most relevant journals on these issues are published in English, other languages are almost irrelevant in this topic (apart from German, French, or Spanish), although it is worth mentioning the growth of Portuguese in this field, due to Brazil, and the position of Ukrainian in Scopus.

Table 2. Languages used in sustainability and retail.

\begin{tabular}{cccc}
\hline & & WOS & SCOPUS \\
\hline Languages & R W/S & Articles & Articles \\
\hline English & $1 / 1$ & 1048 & 1503 \\
Portuguese & $2 / 2$ & 8 & 16 \\
Spanish & $2 / 7$ & 8 & 6 \\
Russian & $4 / 8$ & 6 & 5 \\
Turkish & $5 / 11$ & 2 & 2 \\
Czech & $6 / 14$ & 1 & 1 \\
French & $6 / 4$ & 1 & 14 \\
German & $6 / 3$ & 1 & 15 \\
Japanese & $6 / 10$ & 1 & 2 \\
Chinese & $-/ 5$ & - & 7 \\
Ukrainian & $-/ 5$ & - & 7 \\
Italian & $-/ 9$ & - & 4 \\
Slovenian & $-/ 11$ & - & 2 \\
Bulgarian & $-/ 12$ & - & 1 \\
Dutch & $-/ 12$ & - & 1 \\
Hungarian & $-/ 12$ & - & 1 \\
Korean & $-/ 12$ & - & 1 \\
Swedish & $-/ 12$ & - & 1 \\
\hline R W S: Ranking on WOS (W) and Scopus (S) databases.
\end{tabular}

\subsection{Evolution of the Number of Publications Per Year}

The first article on sustainability and retailing collected by Scopus is from 1981, and it confronts the existing problem of coral, since consumer countries do little to try to reduce retail trade [45]. Since that year, and until the beginning of the 21st century, there are only a few publications on this subject. Something similar occurs in WOS, maintaining a low volume of publications during the first years. The first article in WOS is from 1992, about how the strategic groups concept can provide structure for the analysis of strategies in competitive environments, using the supermarket retailing industry as an example [46].

As mentioned, during the first years, growth of publications addressing this topic was moderate. However, from 2014, a much faster growth is seen, reaching 231 articles in 2017 (WOS), which represents a growth of $40.8 \%$ with respect to 2016 . Therefore, this field is currently becoming a subject of great interest and impact, both in practice and for the academy. Figure 3 shows the historical evolution of published articles on these topics (both in WOS and Scopus). 


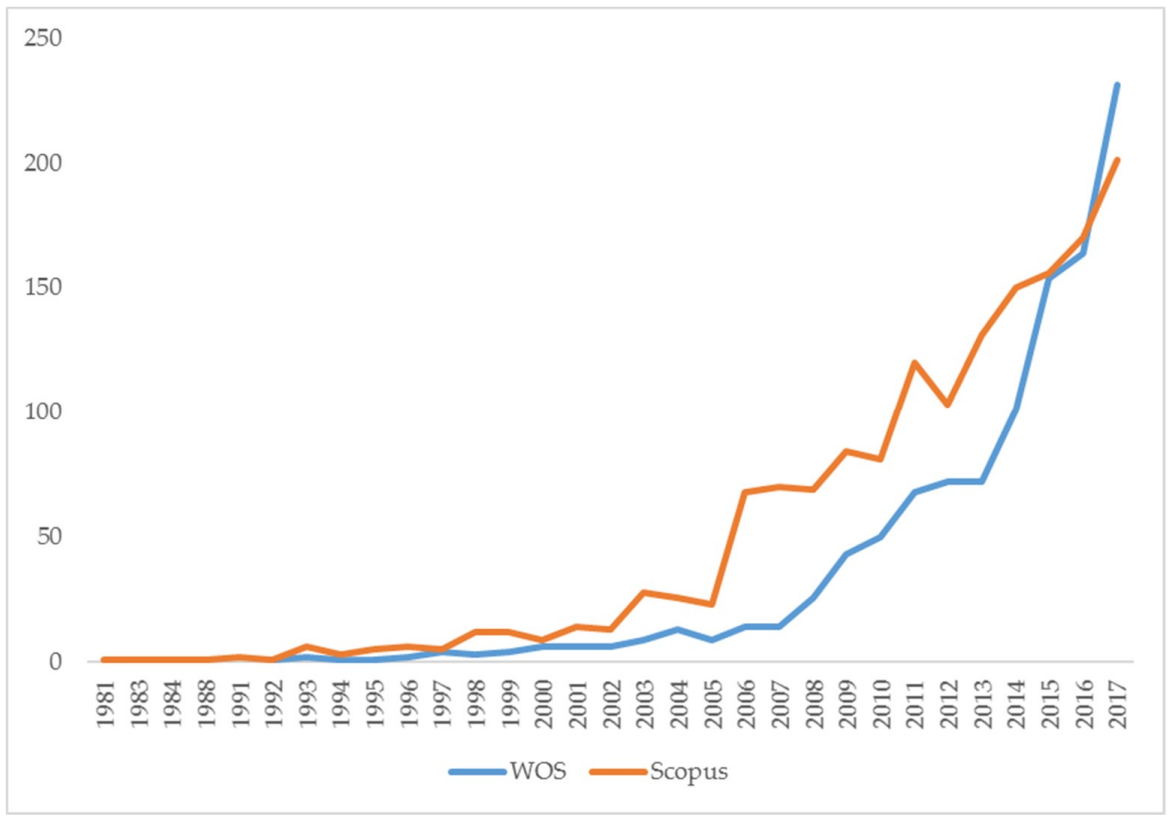

Figure 3. Annual evolution of number of publications (WOS and Scopus).

Regarding annual citations (Figure 4), it goes in parallel to annual evolution of the number of publications, although some differences can be appreciated. For example, 1997 was a year with a high volume of citations per article, both in WOS (159.25) and in Scopus (250.80). In both cases, this is due to a very high number of citations of a single article. In WOS, one article had 584 citations [47], which examined the importance of business-specific effects on the profitability of U.S. public corporations and found that the importance of the effects differs substantially across broad economic sectors, with a larger portion in wholesale and retail trade and transportation. While in Scopus, [48] examines the Information Technology (IT) literature, develops an integrative, resource-based theoretical framework, and presents results from a new empirical study in the retail industry, obtaining 1186 citations so far, and being the article with the most citations of the entire historical series.

To date, 2012 has been the year with the highest h-index in WOS (25) and Scopus (26) databases, in which 2011 also had a h-index of 26. Obviously, articles published in recent years have still fewer citations as those published in previous years.

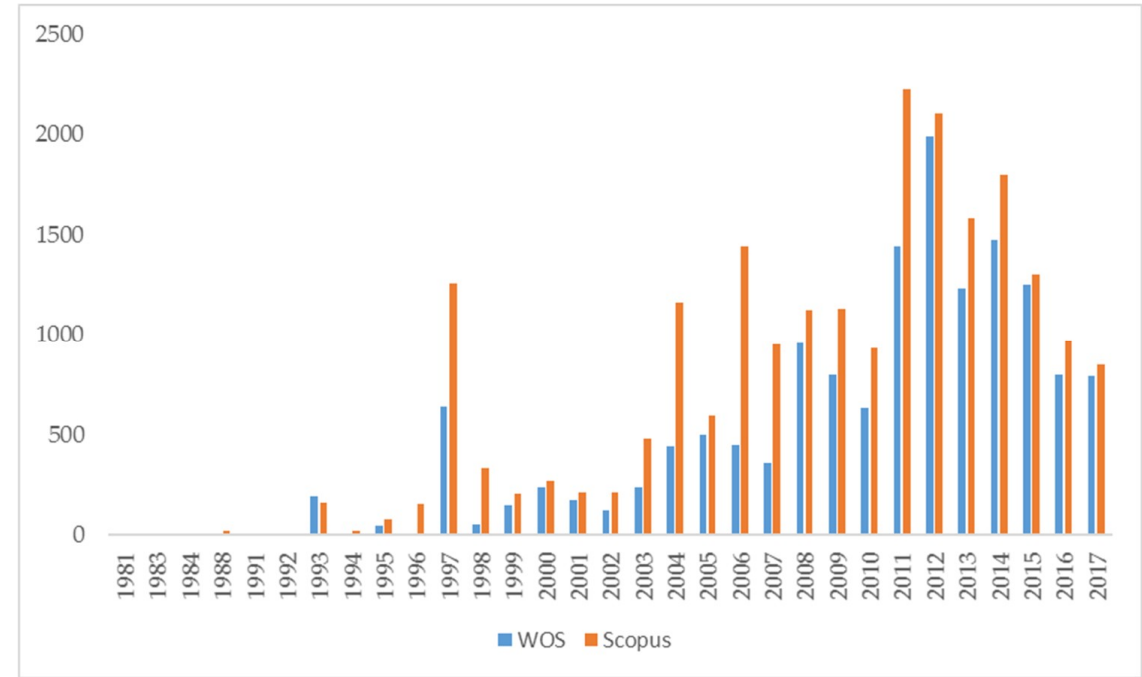

Figure 4. Annual citations (WOS and Scopus). 


\subsection{Most Influential Journals}

There are articles related to retailing and sustainability in a wide range of journals and different areas of knowledge, which shows their importance in the academy in the last years. By focusing the analysis on those journals whose publications represent at least $1 \%$ of the total on these topics, we identified 7 journals in WOS, and 5 in Scopus (Table 3). The 10 most prolific journals represent 18.9\% (WOS) and 13.6\% (Scopus) of total publications, and there are only a few journals (7 in WOS, and 5 in Scopus) whose publications on this topic reach $1 \%$ of the total. Thus, we can affirm that there is not a high concentration of publications in a single journal, but that there are many journals interested in this subject. Depending on the database consulted (Table 3), there are two journals that lead the number of publications on these issues: Journal of Cleaner Production (WOS, 53 articles), and Sustainability (Scopus, 48 articles).

Attending to h-index, Journal of Cleaner Production has the highest h-index (17), followed by International Journal of Production Economics (13-WOS, 12-Scopus). There are other journals of great relevance in this field, according to h-index, such as: International Journal of Retail and Distribution Management, Journal of Retailing and Consumer Services, or British Food Journal.

According to the number of citations, we can highlight Journal of Cleaner Production (894-Scopus, 777-WOS), International Journal of Production Economics (782-WOS), International Journal of Production Economics (763-Scopus), and Food Policy (689-Scopus). Attending to average citations per article, other journals are also relevant: Food Policy (76.56-Scopus; 57.73-WOS), Journal of Retailing (55.58-Scopus; 48.13-WOS), International Journal of Production Economics (54.50-Scopus; 43.44-WOS), or Supply Chain Management and International Journal (59.5-Scopus; 35.78-WOS). Journal of Rural Studies, with only 4 articles, has an average of 81 citations per article, due to the high number of citations of the papers "Rural development and the regional state: Denying multifunctional agriculture in the UK" [49], and "The city in the country: Growing alternative food networks in Metropolitan areas" [50], which have been cited 196 and 184 times, respectively, in the WOS Core Collection.

Table 3. Journals and impact (WOS and Scopus).

\begin{tabular}{|c|c|c|c|c|c|c|c|c|c|}
\hline \multirow[b]{2}{*}{ Journal } & \multirow[b]{2}{*}{ R W/S } & \multicolumn{2}{|c|}{ WOS } & \multicolumn{6}{|c|}{ SCOPUS } \\
\hline & & $\mathbf{A}$ & $C$ & C/A & h-i & A & $\mathrm{C}$ & C/A & h-i \\
\hline Journal of Cleaner Production & $1 / 2$ & 53 & 777 & 14.66 & 17 & 42 & 894 & 21.29 & 17 \\
\hline Sustainability & $2 / 1$ & 50 & 262 & $5 . .24$ & 8 & 48 & 341 & 7.10 & 9 \\
\hline International Journal of Production Economics & $3 / 6$ & 18 & 782 & 43.44 & 13 & 14 & 763 & 54.50 & 12 \\
\hline British Food Journal & $4 / 5$ & 16 & 194 & 12.13 & 9 & 18 & 399 & 22.17 & 10 \\
\hline $\begin{array}{l}\text { International Journal of Retail } \\
\text { Distribution Management }\end{array}$ & $4 / 3$ & 16 & 74 & 4.63 & 6 & 33 & 397 & 12.03 & 12 \\
\hline Food Policy & $6 / 10$ & 11 & 635 & 57.73 & 9 & 9 & 689 & 76.56 & 9 \\
\hline International Journal of Consumer Studies & $6 / 7$ & 11 & 139 & 12.64 & 9 & 11 & 160 & 14.55 & 8 \\
\hline European Journal of Operational Research & 8 & 10 & 145 & 14.50 & 7 & & & & \\
\hline Business Strategy and The Environment & $9 / 8$ & 9 & 133 & 14.78 & 7 & 10 & 191 & 19.10 & 8 \\
\hline Geoforum & $9 /-$ & 9 & 149 & 16.56 & 6 & & & & \\
\hline International Journal of Life and Cycle Assessment & $9 / 8$ & 9 & 285 & 31.67 & 8 & 10 & 355 & 35.50 & 9 \\
\hline Marine Policy & $9 /-$ & 9 & 74 & 8.22 & 5 & & & & \\
\hline Resources Conservation and Recycling & $9 / 12$ & 9 & 165 & 18.33 & 7 & 8 & 179 & 22.38 & 7 \\
\hline Supply Chain Management an International Journal & $9 / 12$ & 9 & 322 & 35.78 & 7 & 8 & 476 & 59.50 & 7 \\
\hline Journal of Retailing & $10 / 12$ & 8 & 385 & 48.13 & 6 & 8 & 447 & 55.88 & 6 \\
\hline Springer Series in Fashion Business & 1 & 8 & 2 & 0.25 & 1 & & & & \\
\hline Journal of Retailing and Consumer Services & $-/ 4$ & & & & & 19 & 303 & 15.95 & 12 \\
\hline Acta Horticulturae & $-/ 10$ & & & & & 9 & 29 & 3.22 & 3 \\
\hline Sustainable Business & $-/ 12$ & & & & & 8 & 0 & 0.00 & 0 \\
\hline Wit Transactions on Ecology and Environment & $-/ 12$ & & & & & 8 & 9 & 1.13 & 2 \\
\hline
\end{tabular}

R W/S: Ranking on WOS (W) and Scopus (S) databases. A: total number of articles. C: total number of citations in total articles. C/A: average citations per article. h-i: Hirsch index.

Table 4 shows the top five articles according to the number of citations. The most cited article is "Information technology as competitive advantage: The role of human, business, and technology 
resources" [48], with 1186 citations (Scopus), published by Strategic Management Journal. This paper researches linkages between IT and firm performance, and the findings show that IT alone has not produced sustainable performance advantages in the retail industry, but that some firms have gained advantages by using IT to leverage intangible and complementary human and business resources. The second paper in the ranking of most cited articles (Table 4) is "Closed-Loop Supply Chain Models with Product Remanufacturing" [51], with 924 citations (Scopus). This paper was published by Management Science and finds that, when considering decentralized channels, ceteris paribus, the agent who is closest to the customer (i.e., the retailer), is the most effective undertaker of product collection activity for the manufacturer. The third article in this ranking is "Firm performance impacts of digitally enabled supply chain integration capabilities" [52], with 830 citations (Scopus). This work collected data from 110 supply chain and logistics managers in manufacturing and retail organizations and suggests that integrated IT infrastructures enables firms to develop higher-order capability of supply chain process integration. The fourth article of the ranking is "How much does industry matter, really?" [47], with 584 citations (WOS), which examines the importance of year, industry, corporate-parent, and business-specific effects on the profitability of U.S. public corporations within specific 4-digit SIC categories. It finds that the importance of the effects differs substantially across broad economic sectors, and that industry effects account for a larger portion in wholesale and retail trade. The fifth article is "Third-party certification in the global agrifood system" [29], with 316 citations (Scopus). This paper concludes that third-party certification reflects the growing power of supermarkets to regulate the global agrifood system. At the same time, third-party certification also offers opportunities to create alternative practices that are more socially and environmentally sustainable. Other relevant articles are: "Towards a sustainable fashion retail supply chain in Europe: Organization and performance" [53], with 235 citations (Scopus), which discusses how the sustainability movement is impacting the fashion retail supply chain organization and its performance. Additionally, "New! Improved? The transformation of the global agrifood system" [54], with 199 citations (WOS), examines changes in the agrifood system made possible by the World Trade Organization and concludes that today it is the private sector, and retailers in particular, together with private standards that are at the center of the transformation of the global agrifood system.

Table 4. Top five articles according to the number of citations.

\begin{tabular}{|c|c|c|c|c|c|}
\hline $\mathbf{R}$ & Article & $\mathrm{C}$ & Year & Authors & Journal \\
\hline 1 & $\begin{array}{l}\text { Information technology as competitive } \\
\text { advantage: The role of human, business, } \\
\text { and technology resources }\end{array}$ & 1186 (Scopus) & 1997 & $\begin{array}{c}\text { Powell, T.C., } \\
\text { Dent-Micallef, A. }\end{array}$ & $\begin{array}{l}\text { Strateg. } \\
\text { Manage. J. }\end{array}$ \\
\hline 2 & $\begin{array}{l}\text { Closed-Loop Supply Chain Models with } \\
\text { Product Remanufacturing }\end{array}$ & 924 (Scopus) & 2004 & $\begin{array}{l}\text { Savaskan, R.C., } \\
\text { Bhattacharya, S., Van } \\
\text { Wassenhove, L.N. }\end{array}$ & $\begin{array}{l}\text { Management } \\
\text { Sci. }\end{array}$ \\
\hline 3 & $\begin{array}{l}\text { Firm performance impacts of digitally } \\
\text { enabled supply chain } \\
\text { integration capabilities }\end{array}$ & 830 (Scopus) & 2006 & $\begin{array}{l}\text { Rai, A., Patnayakuni, } \\
\text { R., Seth, N. }\end{array}$ & MIS Quarterly \\
\hline 4 & How much does industry matter, really? & 584 (WOS) & 1997 & $\begin{array}{l}\text { McGahan, AM; } \\
\text { Porter, ME }\end{array}$ & $\begin{array}{l}\text { Strateg. } \\
\text { Manage. J. }\end{array}$ \\
\hline 5 & $\begin{array}{l}\text { Third-party certification in the global } \\
\text { agrifood system }\end{array}$ & 316 (WOS) & 2005 & $\begin{array}{l}\text { Hatanaka, M., Bain, } \\
\text { C., Busch, L. }\end{array}$ & Food Policy \\
\hline
\end{tabular}

R: Ranking. C: total number of citations in total articles.

\subsection{Most Relevant Authors and Cited References}

The impact of an article can be measured by considering the number of citations (i.e., other papers which refer to it). Thus, this research differentiates between two bibliometric indicators to analyze the most relevant authors: number of articles and author citations. According to the databases, publications on this topic are widely dispersed among a large group of authors (Table 5). The most prolific scholars are Professors Comfort, Hiller and Jones (10 articles-Scopus), Choi (8-WOS, 5-Scopus), and Shen (7-WOS; 5-Scopus). 
The most influential author, according to the number of citations, is Professor Tsan-Ming Choi, from The Hong Kong Polytechnic University, who has been cited 236 times (Scopus). Other authors with a large number of citations are Professors Shen (166-Scopus) and Bourlakis (135-Scopus). These same authors are also those that have a higher h-index: Shen (6-WOS), Choi (5-WOS), Shen (5-Scopus), and Bourlakis (5-Scopus). Professor Choi reaches an average of 47.20 citations per article, mainly from two papers: "Local sourcing and fashion quick response system: The impacts of carbon footprint tax" [55] (80 citations), which analytically studies how a properly designed carbon footprint taxation scheme can be imposed on a quick response system to enhance environmental sustainability via employing a local manufacturer in fashion retailing; and "Mean-downside-risk and mean-variance newsvendor models: Implications for sustainable fashion retailing" [56] (79 citations), which explores the mean-downside-risk and mean-variance newsvendor models under both the exogenous and endogenous retail price decision cases.

Table 5. Most relevant authors.

\begin{tabular}{|c|c|c|c|c|c|c|c|c|c|}
\hline \multirow[b]{2}{*}{ Author } & \multirow[b]{2}{*}{ R W/S } & \multicolumn{2}{|c|}{ WOS } & \multicolumn{6}{|c|}{ SCOPUS } \\
\hline & & A & $\mathrm{C}$ & C/A & h-Index & A & $\mathrm{C}$ & C/A & h-Index \\
\hline Choi, TM. & $1 / 6$ & 8 & 207 & 25.88 & 5 & 5 & 236 & 47.20 & 4 \\
\hline Shen, B. & $2 / 4$ & 7 & 161 & 23.00 & 6 & 6 & 166 & 27.67 & 5 \\
\hline Stahle, J. & $3 /-$ & 7 & 2 & 0.29 & 1 & & & & \\
\hline Erol, I. & $4 /-$ & 4 & 124 & 31.00 & 2 & & & & \\
\hline Dauvergne, P. & $5 / 8$ & 4 & 104 & 26.00 & 3 & 4 & 131 & 32.75 & 3 \\
\hline Lister, $\mathrm{P}$ & $6 / 8$ & 4 & 100 & 25.00 & 3 & 4 & 131 & 32.75 & 3 \\
\hline Marcucci, E. & $7 /-$ & 4 & 90 & 22.50 & 3 & & & & \\
\hline Mench, JA. & $8 /-$ & 4 & 69 & 17.25 & 3 & & & & \\
\hline Eriksson, M. & $9 /-$ & 4 & 65 & 16.25 & 4 & & & & \\
\hline Hartmann, M. & $10 /-$ & 4 & 60 & 15.00 & 3 & & & & \\
\hline Fisher, C & $10 /-$ & 4 & 60 & 15.00 & 3 & & & & \\
\hline Fuente, C. & $12 / 12$ & 4 & 49 & 12.25 & 4 & 4 & 56 & 14.00 & 4 \\
\hline Rieradevall, J. & $13 /-$ & 4 & 33 & 8.25 & 2 & & & & \\
\hline Toppinen, A. & $14 / 13$ & 4 & 27 & 6.75 & 2 & 4 & 30 & 7.50 & 3 \\
\hline Jones, $\mathrm{P}$ & $15 /-$ & 4 & 22 & 5.50 & 2 & & & & \\
\hline Dylst, P. & $16 /-$ & 4 & 17 & 4.25 & 3 & & & & \\
\hline Simoens, S. & $16 /-$ & 4 & 17 & 4.25 & 3 & & & & \\
\hline Comfort, D. & $-/ 1$ & & & & & 10 & 68 & 6.80 & 4 \\
\hline Hiller, D & $-/ 2$ & & & & & 10 & 65 & 6.50 & 4 \\
\hline Jones, P. & $-/ 2$ & & & & & 10 & 65 & 6.50 & 4 \\
\hline Bourlakis, M. & $-/ 5$ & & & & & 5 & 135 & 27.00 & 5 \\
\hline Dos Santos, M.A.O. & $-/ 7$ & & & & & 5 & 51 & 10.20 & 3 \\
\hline Aschemann-Witzel & $-/ 10$ & & & & & 4 & 70 & 17.50 & 4 \\
\hline Svensson, G & $-/ 10$ & & & & & 4 & 70 & 17.50 & 3 \\
\hline Lehner, M. & $-/ 11$ & & & & & 4 & 69 & 17.25 & 3 \\
\hline Paché, G & $-/ 14$ & & & & & 4 & 10 & 2.50 & 2 \\
\hline
\end{tabular}

R W/S: Ranking on WOS (W) and Scopus (S) databases. A: total number of articles. C: total number of citations in total articles. C/A: average citations per article. h-index: Hirsch index.

Figure 5 shows a co-citation map based on bibliographic WOS data. Co-citation by cited authors was obtained by using fractional counting. The minimum number of citations of an author has been established as 20. 102 references out of a total of 29,517 reach the threshold. For each of the 102 authors, the total strength of the co-citations links with other authors has been calculated. The authors with the greatest total link strength have been selected and grouped into 6 clusters. The most influential authors from each cluster can be easily identified in most of the groups. Indicating the most important topic and elements of every cluster would be helpful to identify the main research trends on the subject, and to promote alliances, collaboration, and networking.

The leader of cluster 1 (red color) is Professor Michael Porter, and it is composed of 25 authors, which makes it the largest group. The importance of this cluster is evident, being around the 
fundamental role of the value chain and innovation, sustainability, and the five forces model, or sustainable competitive advantages and how to create superior performance, all of them very important issues in sustainable models.

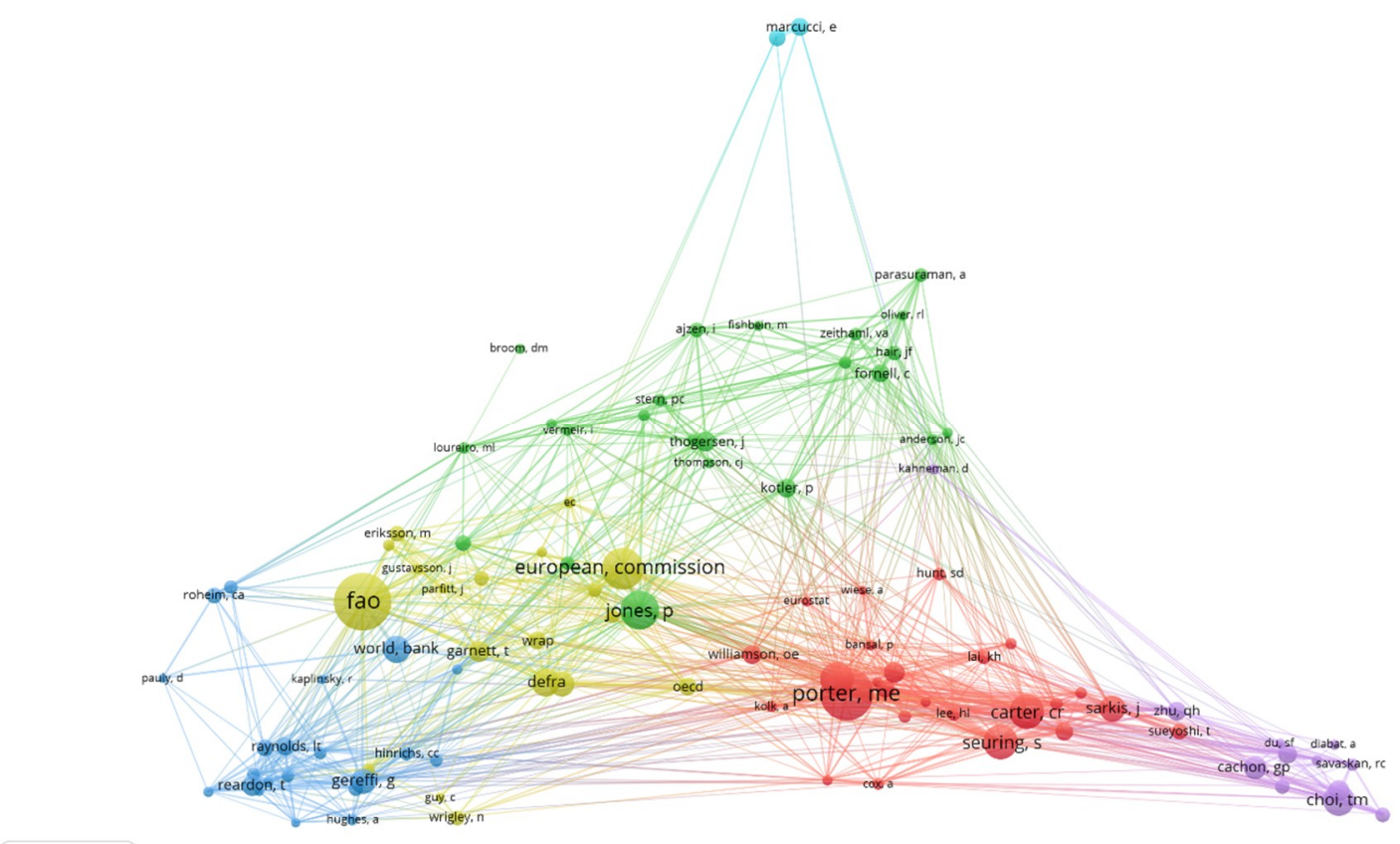

绐 vosviewer

Figure 5. Co-citation map based on bibliographic data.

Cluster 2 (dark green), composed of 23 authors, and lead by authors such as Professors Philip Kotler, A. Parasuraman, John Thogersen, and Claes Fornell, is mainly focused on marketing and sustainability for retailers, researching related topics such as the impact of the marketing mix and sustainability on shaping consumer references, the role of sustainable visual merchandising practices in predicting retail store loyalty, or determinants of retail customer satisfaction.

Cluster 3 (blue) has 21 items, the World Bank being one of the most outstanding. The World Bank Group is a unique global partnership fighting poverty worldwide through sustainable solutions, which supports different programs such as retail payments, raising environmental, health, and safety standards for retailers, bonds for sustainable development, or programs aimed at strategic industries for sustainable growth, such as tourism, retail, or property.

Cluster 4 (light green), composed of 19 authors and institutions, has two main entities leading the group, FAO (Food and Agriculture Organization) and European Commission. This cluster is mainly focused on food, on matters such as: sustainability in the global food system; developing sustainable food supply chains; quality, safety, and sustainability in food distribution; development of measuring methods for environmental sustainability in food production systems; or drivers for sustainable food retailing. Another issue of interest to this group is related to the European Union, researching on sustainable retail supply chain in Europe, such as: European retailers as agents of change towards sustainability; private eco-brands and green market development; or analyzing retailers' sensitivity to local sustainability policies. Other institutions are also part of this cluster, for example: United Nations, UNEP (United Nations Environment Programme), OECD (The Organization for Economic Co-operation and Development), and WRAP (Worldwide Responsible Accredited Production).

Professor Tsan-Ming Choi, one of the most influential authors of sustainability in retailing, is the leader of cluster 5 (purple), which has 12 authors, and the cluster is focused on sustainable fashion retailing and on the impacts of carbon footprint tax. 
Finally, cluster 6 (light blue) is the smallest group, with just 2 authors (Professors Edoardo Marcucci and Jose Holguin-Veras), and it has no leader, being related to various issues within sustainability and retailers.

\subsection{Main Areas of Knowledge}

A very important factor for knowing the current context and trends in publications on the topics considered (sustainability in retailing) is to identify the main areas of knowledge that collect the articles, and in which ones this subject is an emerging source for the academy. Given that these topics, mainly sustainability, have a rather transversal nature, there are a wide variety of areas of knowledge dealing with this subject.

Although many articles are framed in more than one area of knowledge, it can be argued that the most prominent fields in WOS are (Figure 6) Environmental Sciences, with 197 articles, i.e. $18.3 \%$ of total publications about these topics, and Business, with 173 articles (16.4\%). In Scopus, we identified Business, Management and Accounting, with 631 articles (40.1\%), Social Sciences, 464 articles, (29.5\%), and Environmental Sciences, 408 articles (25.9\%) (Figure 7).

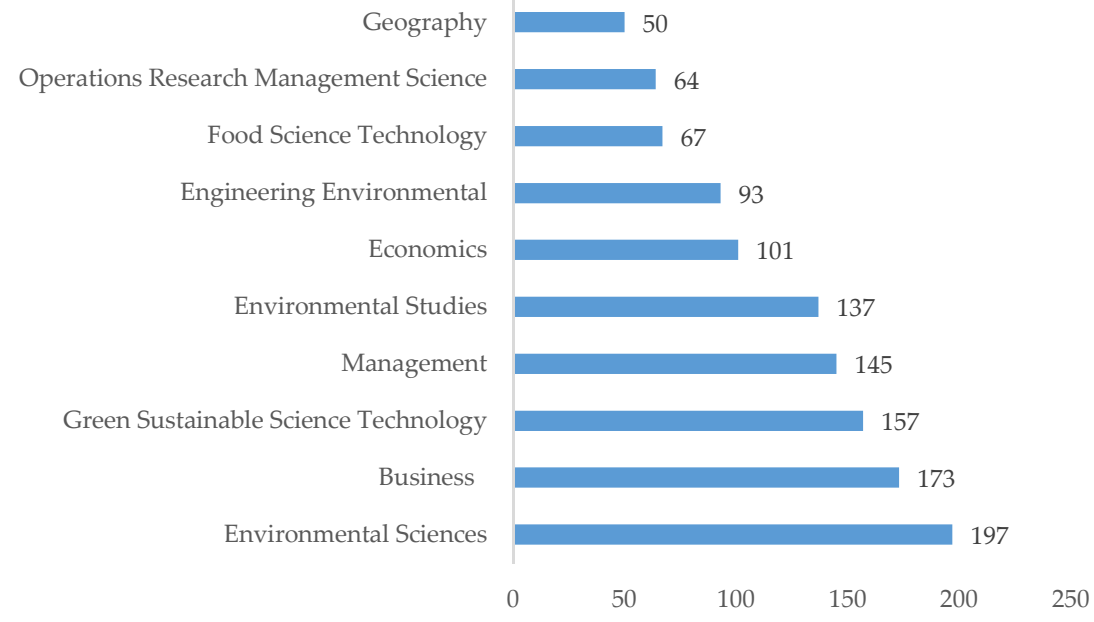

Figure 6. Number of articles published by areas of knowledge (WOS).

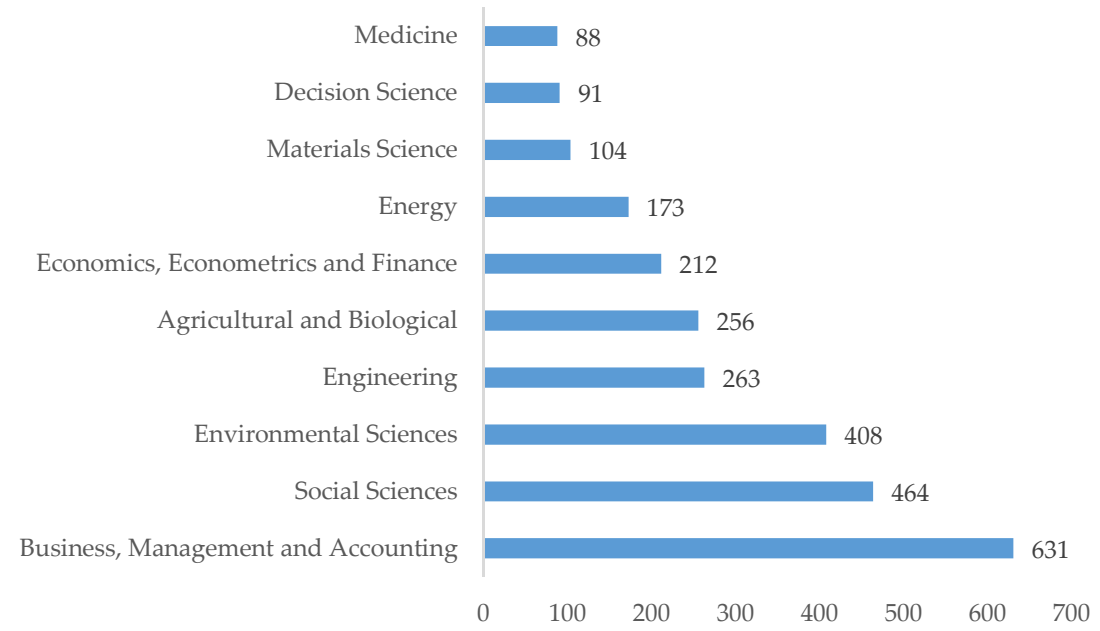

Figure 7. Number of articles published by areas of knowledge (Scopus).

According to the h-index, the most relevant areas of knowledge in WOS are (Table 6): Environmental Sciences (29), Management (27), Operations Research Management Science (26), and Business (25). Regarding Scopus (Table 7), the following fields have the highest h-index: Business, Management and Accounting (44), Environmental Sciences (38), and Social Sciences (34). 
Table 6. Top ten areas of knowledge (WOS).

\begin{tabular}{cccccc}
\hline Ranking & Area of Knowledge & Articles & Citations & C/A & h-Index \\
\hline 1 & Environmental Sciences & 197 & 2908 & 14.76 & 29 \\
2 & Business & 173 & 2912 & 16.83 & 25 \\
3 & Green Sustainable Science Technology & 157 & 1447 & 9.22 & 20 \\
4 & Management & 145 & 2733 & 18.85 & 27 \\
5 & Environmental Studies & 137 & 1270 & 9.27 & 18 \\
6 & Economics & 101 & 1656 & 16.40 & 21 \\
7 & Engineering Environmental & 93 & 1592 & 17.12 & 23 \\
8 & Food Science Technology & 67 & 1147 & 17.12 & 19 \\
9 & Operation Research Management Science & 64 & 1819 & 28.42 & 26 \\
10 & Geography & 50 & 1145 & 22.90 & 16 \\
\hline
\end{tabular}

C/A: average citations per article. h-index: Hirsch index.

Table 7. Top ten areas of knowledge (Scopus).

\begin{tabular}{cccccc}
\hline Ranking & Area of Knowledge & Articles & Citations & C/A & h-Index \\
\hline 1 & Business, Management and Accounting & 631 & 11,366 & 18.01 & 44 \\
2 & Social Sciences & 464 & 5188 & 11.18 & 34 \\
3 & Environmental Sciences & 408 & 5957 & 14.60 & 38 \\
4 & Engineering & 263 & 3365 & 12.79 & 31 \\
5 & Agricultural and Biological & 256 & 3210 & 12.54 & 28 \\
6 & Economics, Econometrics and Finance & 212 & 3391 & 16.00 & 31 \\
7 & Energy & 173 & 2148 & 12.42 & 24 \\
8 & Materials Science & 104 & 230 & 2.21 & 9 \\
9 & Decision Science & 91 & 3818 & 41.96 & 26 \\
10 & Medicine & 88 & 967 & 10.99 & 16 \\
\hline
\end{tabular}

C/A: average citations per article. h-index: Hirsch index.

Figure 8 shows a map based on WOS data on co-occurrence of the author's keywords from 2012 to 2017 using a fractional counting method. The minimum of occurrences of a keyword was established on eight of the 3351 keywords founded. This map is useful to know trends on research about sustainability and retail and shows the main interactions between the most frequent terms in this research and the existing clusters, highlighting the term "sustainability" as a central figure. On the network analysis, the keywords build clusters and the size of the circle is determined by the weight of the item. The higher the weight of an item, the larger the circle of the item. Lines between items represents links, and the distance between two keywords indicates the relatedness of the keyword in terms of co-occurrence links.

Therefore, seven clusters were identified:

Cluster 1 (red): Certification, consumer, fair trade, governance, marketing, supply chain, sustainable, sustainable agriculture, sustainable consumption, transport.

Cluster 2 (green): Consumer behavior, corporate social responsibility, food industry, food security, retailers, South Africa, sustainable development.

Cluster 3 (blue): Environmental sustainability, LCA (Life Cycle Assessment), recycling, reverse logistic, supply chain, supply chain management.

Cluster 4 (light green): Carbon footprint, food supply chain, food waste, game theory, life cycle assessment, sustainable supply chain.

Cluster 5 (purple): Agriculture, environment, environmental management, food, retail.

Cluster 6 (light blue): Efficiency, innovation, logistics retailing.

Cluster 7 (orange): India, sustainability, sustainable supply chain.

Thus, apart from the central term "sustainability", other relevant topics are highlighted, such as sustainable development, food waste, supply chain, supply chain management, or corporate social responsibility. 


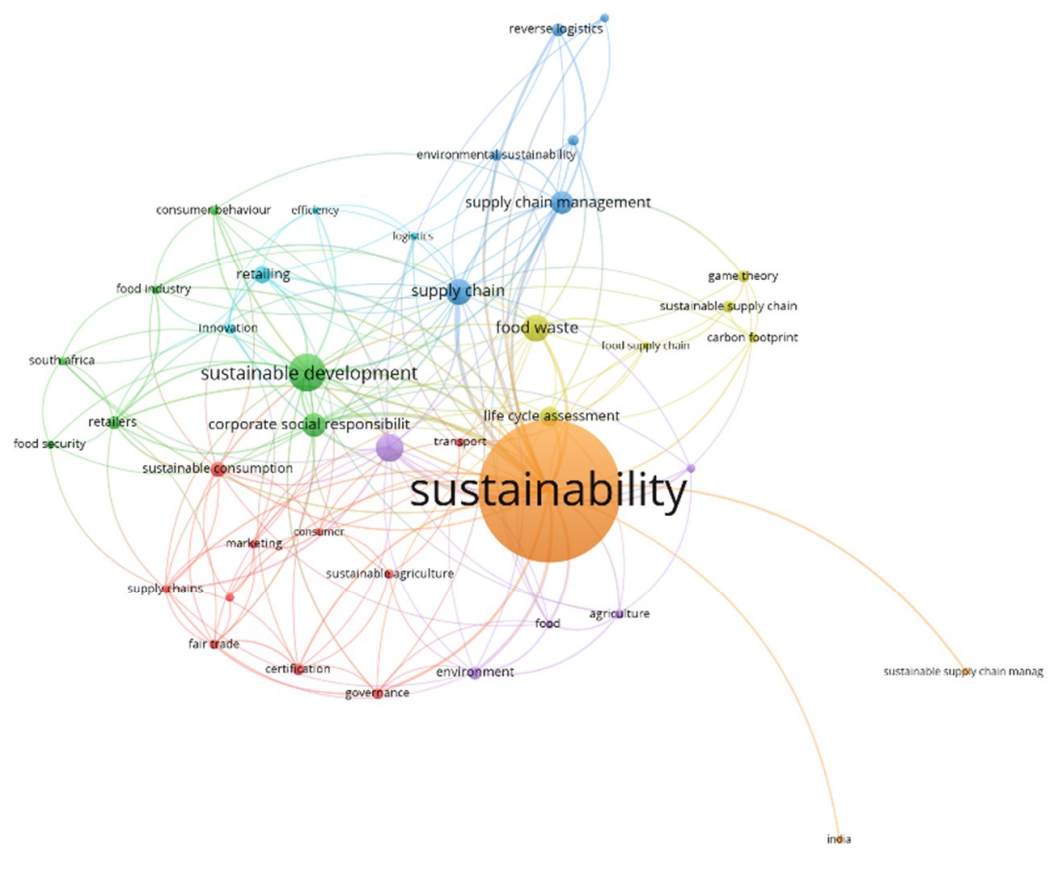

B vosviewer

Figure 8. Map based on co-occurrence on the authors keywords.

In order to analyze the evolution of the most frequent terms used by the authors in research on sustainability and retailers, a trend map is made, using a fractional counting method, attending to the Scopus database and based on bibliographic data on the co-occurrence of the authors keywords (Figure 9). This map is based on the average publications per year and uses different colors to highlight the most employed author keywords in each of the last years. The most recent keywords are marked in yellow, so the most important trends may be identified. Nowadays, research on sustainability in retailing focus on topics such as supply chain and sustainable supply chain, or reverse logistics. The other important emergent subject in retailing is food waste and the efficient management of supermarkets. Other emergent topics regarding retailers are environmental sustainability, carbon footprint, corporate social responsibility, and the triple bottom line.
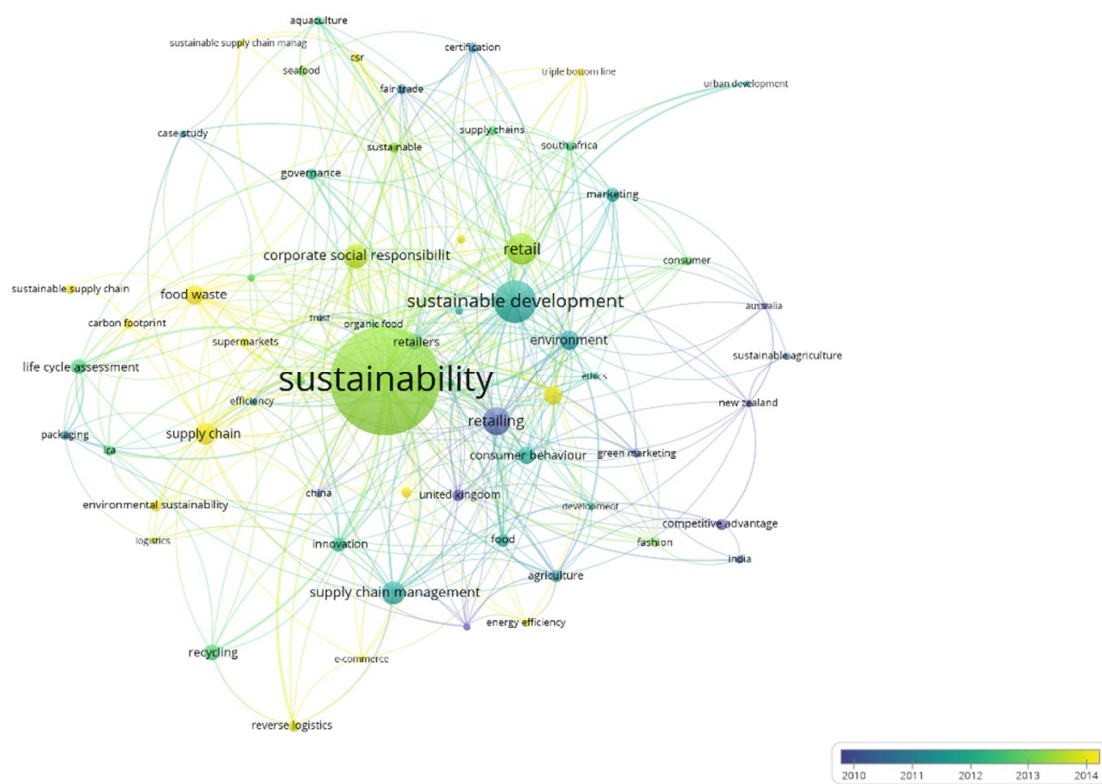

Figure 9. Map based on co-occurrence on the authors keywords, and evolution in recent years. 


\section{Conclusions}

Although the rise of publications on sustainability in retail is relatively recent, driven mainly since 2014 , nowadays it is a very important field, with great potential for development in many different topics. There are different interpretations of sustainability and a wide variety of areas of knowledge in retail research. Also, the methods employed to analyze different issues regarding sustainability in retailing are varied (e.g., theoretical, descriptive, empirical analysis, quantitative analysis), as well as the retailer sectors considered by researchers (e.g., grocery, fashion, food, property, transportation, tourism), the topics or dimensions around sustainability which are analyzed (e.g., certifications, environmental sustainability, supply chains, Corporate Social Responsibility), or the geographical scope of the research (e.g., worldwide, China, Europe, U.S., Australia, United Kingdom, Poland).

The United States and the United Kingdom lead the ranking of the most influential countries in volume of publications, citations, and the h-index. Considering the historical evolution of publications, until the beginning of the 21st century there are only a few articles on this topic and during the first years its growth was moderate. It is from 2014 when this subject was consolidated and aroused greater interest in the scientific community, initiating a stage of rapid growth in the number of annual publications. Nowadays, this field has a great interest and impact in practice, and also for the academy. Articles related to retailing and sustainability may be found in a wide range of journals and different areas of knowledge, which is evidence of its relevance. There are many journals interested in this subject, and although Journal of Cleaner Production and Sustainability lead the number of publications on these issues, there is not a high concentration of publications in a single journal. Thus, Journal of Cleaner Production and International Journal of Production Economics have the highest h-index. According to h-index, there are other relevant journals, such as International Journal of Retail and Distribution Management, Journal of Retailing and Consumer Services, or British Food Journal.

Authors have been grouped into 6 clusters, according to the greatest total link strength. These clusters are focused on diverse subjects, such as: the value chain and the innovation; sustainable competitive advantages; marketing and sustainability for retailers; the impact of the marketing mix and sustainability on consumer references; sustainable visual merchandising practices and retail store loyalty; determinants of retail customer satisfaction; sustainable solutions and programs; raising environmental, health, and safety standards for retailers; bonds for sustainable development; programs for strategic industries for sustainable growth such as tourism, retail, or property; sustainability in the global food system; developing sustainable food supply chains; quality, safety, and sustainability in food distribution; drivers for sustainable food retailing; private eco-brands and green market development; retailers' sensitivity to local sustainability policies; or sustainable fashion retailing.

Sustainability in retail has a transversal nature, thus there are a wide variety of areas of knowledge interested and in the topic. The most prominent fields are environmental sciences, business, and social sciences. By using a fractional counting method to analyze co-occurrence on the author's keywords, this paper identifies the most frequent terms and seven clusters, with the most relevant topics being sustainable development, food waste, sustainable supply chain, supply chain management, or corporate social responsibility.

After the bibliometric analysis of sustainability in retailing, one of the main contributions of the present work is to be able to suggest some future lines of research that may be of interest to the academy. In this sense, we have identified some relevant areas for both scholars and retailers. For instance, it could be interesting to analyze under which conditions the sustainability initiatives work best and give better results to retailers. Processes are also one of the keys for retailers, so another area with great potential for research development is that of selection of suppliers and supply chain management. Regarding products, apart from organic products, which are considered to be sustainable and many articles are focused on them, there are interesting research opportunities focused on other types of sustainable products (e.g., environmentally friendly products). Sustainable stores is also an emergent trend, as is another research field about sales processes and sustainable management of the store. The image of retailers is a key element in retail management, therefore, another priority 
field for academics is to know the intensity with which sustainability actions of retailers help them to improve their image. Closely related to the above, it is also important to know the best way to communicate the sustainability actions of retailers to different audiences. Brand equity is another relevant issue in fields such as business, management, and social sciences. Thus, research may also focus on some possible differences about how sustainability actions influence different types of brands, paying special attention to the difference between national brands and private labels. Finally, another relevant research topic is that of international and cross-cultural analysis, which allows us to know how cultural differences and the environment of countries influence the perception of sustainable initiatives and products.

This work is not exempt from certain limitations, some of which could be the basis for future research. Some of them are derived directly from the characteristics of the bibliometric analysis, which is a method mainly focused on quantitative analysis. Some authors may publish only a few articles but are very influential in their area of knowledge, even having a great impact on a specific field. Thus, apart from using two of the most influential tools for a bibliometric analysis (WOS and Scopus), we also measured qualitative features and standardized metrics, such as the number of citations, or the h-index. Regardless, the methodology of this research could be expanded with other quantitative or qualitative tools (e.g., Google Scholar or meta-analysis), that may provide a different perspective. This research is focused on articles published inn scientific journals; for future research, it would be also interesting including other different types of documents, such as books, or conference papers. Further, this research has carried out a generic analysis on sustainability in retail, focused on articles in which both terms are related. For future bibliometrics analysis, it could be interesting to delve into different fields of this discipline, for more specific research on some of the subjects related to these topics.

Author Contributions: J.L.R.-R., J.U.-T., J.C.G.-A., and J.d.P.V. have contributed in the same way to the writing of this manuscript, and all the authors have read and approved the final manuscript.

Funding: This research received no external funding.

Conflicts of Interest: The authors declare no conflict of interest.

\section{References}

1. Labuschagne, C.; Brent, A.C.; Van Erck, P.C.R. Assessing the sustainability performances of industries. J. Clean. Prod. 2005, 13, 373-385. [CrossRef]

2. Elkington, J. Cannibals with Forks-The Triple Bottom Line of 21st Century Business; New Society: Stony Creek, CT, USA, 1998.

3. European Commission's. Sustainable Consumption and Production and Sustainable Industrial Policy Action Plan. 2008. Available online: https:/ / eur-lex.europa.eu/LexUriServ /LexUriServ.do?uri=COM:2008:0397: FIN:en:PDF (accessed on 27 November 2018).

4. Ytterhus, B.E.; Arnestad, P.; Lothe, S. Environmental initiatives in the retailing sector: An analysis of supply chain pressures and partnerships. Eco-Manag. Audit. 1999, 6, 181-188. [CrossRef]

5. Wiese, A.; Zielke, S.; Toporowski, W. Sustainability in retailing-Research streams and emerging trends. Int. J. Retail Distrib. Manag. 2015, 43. [CrossRef]

6. Whysall, P. Values in the Marketplace: What Is Ethical Retailing? In Leadership and Business Ethics; Springer: Dordrecht, The Netherlands, 2008; pp. 177-193.

7. Maignan, I.; Ferrell, O.C.; Ferrell, L. A stakeholder model for implementing social responsibility in marketing. Eur. J. Mark. 2005, 39, 956-977. [CrossRef]

8. Schwartz-Cowan, R. The consumption junction: A proposal for research strategies on the sociology of technology. In The Social Construction of Technological Systems: New Directions in the Sociology and History of Technology; Bijker, W.E., Hughes, T.P., Pinch, T.J., Eds.; The Guilford Press: London, UK, 1987.

9. Durieu, X. How Europe's retail sector helps promote sustainable production and consumption. Ind. Environ. 2003, 26, 7-10.

10. Arvidsson, A. The ethical economy of customer coproduction. J. Macromark. 2008, 28, 326-338. [CrossRef] 
11. Arvidsson, A. General Sentiment: How Value and Affect Converge in the Information Economy. Sociol. Rev. 2011, 59, 39-59. [CrossRef]

12. Maloni, M.J.; Brown, M.E. Corporate Social Responsibility in the Supply Chain: An Application in the Food Industry. J. Bus. Ethics 2006, 68, 35-52. [CrossRef]

13. Jones, P.; Comfort, D.; Hillier, D. Marketing Sustainable Consumption within Stores: A Case Study of the UK's Leading Food Retailers. Sustainability 2009, 1, 815-826. [CrossRef]

14. Laroche, M.; Bergeron, J.; Barbaro-Forleo, G. Targeting consumers who are willing to pay more for environmentally friendly products. J. Consum. Mark. 2001, 8, 503-520. [CrossRef]

15. Musso, F.; Risso, M. CSR for Retailers' Led Channel Relationships: Evidence from Italian SME Manufacturers. In Human Rights and Ethics: Concepts, Methodologies, Tools, and Applications; Information Resources Management Association, Ed.; IGI Global: Hershey, PA, USA, 2015; pp. 778-794.

16. Wiese, A.; Kellner, J.; Lietke, B.; Toporowski, W.; Zielke, S. Sustainability in retailing-A summative content analysis. Int. J. Retail Distrib. Manag. 2012, 40, 318-335. [CrossRef]

17. Reuter, C.; Foerstl, K.; Hartmann, E.; Blome, C. Sustainable global supplier management: The role of dynamic capabilities in achieving competitive advantage. J. Supply Chain Manag. 2010, 46, 45-63. [CrossRef]

18. Connelly, B.L.; Ketchen, D.J.; Slater, S.F. Toward a 'theoretical toolbox' for sustainability research in marketing. J. Acad. Mark. Sci. 2011, 39, 86-100. [CrossRef]

19. Burchell, J.; Cook, J. Stakeholder dialogue and organisational learning: Changing relationships between companies and NGOs. Bus. Ethics 2007, 17, 35-46. [CrossRef]

20. Newell, G. The strategic significance of environmental sustainability by Australian LPTs. J. Prop. Invest. Financ. 2008, 26, 522-540. [CrossRef]

21. Wagner, T.; Bicen, P.; Hall, Z.R. The dark side of retailing: Towards a scale of corporate social irresponsibility. Int. J. Retail Distrib. Manag. 2008, 36, 124-142. [CrossRef]

22. Trudel, R.; Cotte, J. Does it pay to be good? MIT Sloan Manag. Rev. 2009, 50, 61-68.

23. Newholm, T.; Shaw, D. Studying the ethical consumer: A review of research. J. Consum. Behav. 2007, 6, 253-270. [CrossRef]

24. Jones, P.; Comfort, D.; Hillier, D. Sustainability in the global shop window. Int. J. Retail Distrib. Manag. 2011, 39, 256-271. [CrossRef]

25. Jones, P.; Hillier, D.; Comfort, D.; Eastwood, I. Sustainable retailing and consumerism. Manag. Res. News 2005, 28, 34-44. [CrossRef]

26. Gray, P.C.R.; Wiedeman, P.D. Risk management and sustainable development: Mutual lessons from approaches to the use of indicators. J. Risk Res. 1999, 2, 201-218. [CrossRef]

27. Erol, I.; Cakar, N.; Erel, D.; Sari, R. Sustainability in the Turkish retailing industry. Sustain. Dev. 2009, 17,49-67. [CrossRef]

28. Jahn, G.; Schramm, M.; Spiller, A. The Reliability of Certification: Quality Labels as a Consumer Policy Tool. J. Consum. Policy 2005, 28, 53-73. [CrossRef]

29. Hatanaka, M.; Bain, C.; Busch, L. Third-party certification in the global agrifood system. Food Policy 2005, 30, 354-369. [CrossRef]

30. Jones, C.E.; Sivalingam, K.M.; Agrawal, P.; Chen, J.C. A Survey of Energy Efficient Network Protocols for Wireless Networks. J. Wirel. Netw. 2001, 7, 343-358. [CrossRef]

31. Quak, H.J.; de Koster, M.B.M. Exploring retailers' sensitivity to local sustainability policies. J. Oper. Manag. 2007, 25, 1103-1122. [CrossRef]

32. Bouyssou, D.; Marchant, T. Ranking scientists and departments in a consistent manner. J. Am. Soc. Inf. Sci. Technol. 2011, 62, 1761-1769. [CrossRef]

33. Brereton, P.; Kitchenham, B.A.; Budgen, D.; Turner, M.; Khalil, M. Lessons from applying the systematic literature review process within the software engineering domain. J. Syst. Softw. 2007, 80, 571-583. [CrossRef]

34. Schafer, A.; Crane, A. Addressing Sustainability and Consumption. J. Macromark. 2005, 25, 76-92. [CrossRef]

35. Garfield, E. Citation Index for Science. A New Dimension in Documentation through Association of Ideas. Science 1955, 122, 108-111. [CrossRef]

36. Guz, A.N.; Rushchitsky, J.J. Scopus: A system for the evaluation of scientific journals. Int. Appl. Mech. 2009, 45, 351-362. [CrossRef]

37. Goodman, D.; Deis, L. Web of Science (2004 version) and Scopus. Charlest. Advis. 2005, 6, 5-21. 
38. Bakkalbasi, N.; Bauer, K.; Glover, J.; Wang, L. Three options for citation tracking: Google Scholar. Scopus and Web of Science. BMC Biomed. Digit. Libr. 2006, 3, 1-8. [CrossRef] [PubMed]

39. Salvador-Oliván, J.A.; Agustín-Lacruz, C. Correlación entre indicadores bibliométricos en revistas de Web of Science y Scopus. Revista General de Información y Documentación 2015, 25, 341-359.

40. Moed, H.F. Citation Analysis in Research Evaluation; Springer: Dordrecht, The Netherlands, 2005.

41. Merton, R.K. The sociology of science: An episodic memoir. In The Sociology of Science in Europe; Merton, R.K., Gaston, J., Eds.; Southern Illinois University Press: Carbondale, IL, USA, 1977; pp. 3-141.

42. Hirsch, J.E. An index to quantify an individual's scientific research output. Proc. Natl. Acad. Sci. USA 2005, 102, 16569-16572. [CrossRef] [PubMed]

43. 14th Annual Consumer Report 2016 State of Sustainability in America. Available online: https:/ / www.nmisolutions.com/index.php/research-reports/sustainability-reports/14th-annualconsumer-report-2016-state-of-sustainability-in-america (accessed on 27 November 2018).

44. Retail Industry Leaders Association (RILA). The Value of Sustainability in Retail Marketing. 2016. Available online: http:/ / www.retailcrc.org/sustainability/Lists/Briefings/Attachments/14/RILA\% 20Issue \%20Brief\%20-\%20The\%20Value\%20of\%20Sustainability\%20in\%20Retail\%20Marketing.pdf (accessed on 27 November 2018).

45. Wells, S.M. International Trade in Ornamental Corals and Shells. In Proceedings of the 4th International Coral Reef Symposium, Manila, Philippines, 18-22 May 1981; pp. 323-330.

46. Carroll, C.; Lewis, P.M.; Thomas, H. Developing competitive strategies in retailing. Long Range Plan. 1992, 25, 81-88. [CrossRef]

47. McGahan, A.M.; Porter, M.E. How much does industry matter, really? Strateg. Manag. J. 1997, 18, 15-30. [CrossRef]

48. Powell, T.C.; Dent-Micallef, A. Information technology as competitive advantage: The role of human, business, and technology resources. Strateg. Manag. J. 1997, 18, 375-405. [CrossRef]

49. Marsden, T.; Sonnino, R. Rural development and the regional state: Denying multifunctional agriculture in the UK. J. Rural Stud. 2008, 24, 422-431. [CrossRef]

50. Jarosz, L. The city in the country: Growing alternative food networks in Metropolitan areas. J. Rural Stud. 2008, 24, 231-244. [CrossRef]

51. Savaskan, R.C.; Bhattacharya, S.; Van Wassenhove, L.N. Closed-Loop Supply Chain Models with Product Remanufacturing. Manag. Sci. 2004, 50, 239-252. [CrossRef]

52. Rai, A.; Patnayakuni, R.; Seth, N. Firm performance impacts of digitally enabled supply chain integration capabilities. MIS Q. Manag. Inf. Syst. 2006, 30, 225-246. [CrossRef]

53. de Brito, M.P.; Carbone, V.; Blanquart, C.M. Towards a sustainable fashion retail supply chain in Europe: Organisation and performance. Int. J. Prod. Econ. 2008, 114, 534-553. [CrossRef]

54. Busch, L.; Bain, C. New! Improved? The transformation of the global agrifood system. Rural Sociol. 2004, 69, 321-346. [CrossRef]

55. Choi, T.M. Local sourcing and fashion quick response system: The impacts of carbon footprint tax. Transp. Res. E Log. 2013, 55, 43-54. [CrossRef]

56. Choi, T.M.; Chiu, C.H. Mean-downside-risk and mean-variance newsvendor models: Implications for sustainable fashion retailing. Int. J. Prod. Econ. 2012, 135, 552-560. [CrossRef]

(C) 2018 by the authors. Licensee MDPI, Basel, Switzerland. This article is an open access article distributed under the terms and conditions of the Creative Commons Attribution (CC BY) license (http:/ / creativecommons.org/licenses/by/4.0/). 